\title{
水溶液中におけるピラジナミドとイソニアジドの䤮体形成の可能性
}

\author{
田村一雄, 酒井久仁雄* \\ 富山学災病院薬郕部*
}

\section{Complex Formation from Pyrazinamide and Isoniazid in Aqueous Solution}

\author{
KAZUO TAMURA, KUNIO SAKAI* \\ Pharmacy, Toyama Rosai Hospital*
}

\begin{abstract}
The complex formation between pyrazinamide and isoniazid was studied in the HiguchiLach method. The solubility of pyrazinamide increased in parallel with isoniazid concentration at $25^{\circ}$, indicating a complex formation. The increase in solubility of pyrazinamide is due to a complex formation and continues until the solubility of the complex reaches the limit. The results of the experiment indicate that the complex is formed by pyrazinamide and isoniazid mixed at equal ratio. This is substantiated by the finding that the equilibrium constant in the experiment remained stable in the whole range of concentrations.
\end{abstract}

\section{铛}

抗結核薬としてのイソニアジドは他種抗結核薬との併 用療法が原則とされ，ピラジナミドとの併用投与によっ ては, 両者の抗菌力が増強されるとともに, 耐性上昇を 著しく遅延することが知られている1゙が，今までに両者 の水溶液中に打相互作用については研究報告がな い. 著者ら 2 は抗結核薬併用療法にしばしば使われるイ ソニアジドとパラアミノサリチル酸カルシウムのの相互作 用について報告したが, 今回はイソニアジドとピラジナ ミドの水溶液中に打ける相互作用を検討した結果，イン ニアジドの共存により水にやや難溶性のピラジナミドの 溶解度が著しく上昇することを認めた．これは水溶性の 大きな錯体形成によるものであることが考えられる．錯 体を純粋に分離し，その性質を測定する必要があるが， 錯体を分離することが極めて困難であるため著者らは Higuchi $5^{3)}$ が ベンゾカインとカフェインの錯体形成 を証明した溶解度法を応用して，ピラジナミドとイソニ アジドとの生成錯体間の化学量論的関係を検討したので 報告する。

实 倹の 部

試 薬

ピラジナミド, イソニアジドは日本薬局方品, その他

* 魚津市六郎丸992; 992, Rokuromaru, Uozu-shi, Toyama, 973 Japan
の試薬は市販品特級を使用した。

アソ゚トメーター

アゾトメーターは既報り の通りである.

\section{定专操作}

\section{ピラジナミドとイソニアジドの定早法}

ピラジナミドは第八改正日本薬局方の定量法 ${ }^{4)}$ に従っ て定量した.イソニアジドの定量法は既報ら)のフェリシ アン化カリウムーアゾトメトリー法に従ったが，この方 法によるときは共存するピラジナミドは窒素ガスを発生 しない.

\section{ピラジナミドとインニアジド共存時の溶解度測定}

過剩量 $(1.0 \mathrm{~g})$ のピラジナミドを $50 \mathrm{~m} \ell$ のコルベンに とり, $20 \mathrm{ml}$ の蒸留水と一定量のイソニアジドを加え, $25^{\circ}$ で 3 時間振とうして平衡に達せしめた後, 沪過し, 沪液 $10 \mathrm{ml}$ についてピラジナミドを定量した. 別に沪液 $1 \mathrm{ml}$ をとり, 蒸留水を加えて全量 $500 \mathrm{ml}$ に希积し, そ の $1 \mathrm{ml}$ をとりフェリシアン化カリウムーアゾトメトリ 一法占によりイソニアジドを定量した. イソニアジドの 添加量を順次増加して得られた結果が Table 1, Fig. 1 である・

\section{結果および考察}

$25^{\circ}$ におけるピラジナミドの溶解度は $1.30 \times 10^{-1} \mathrm{M}$ イソニアジドのそれは $10.43 \times 10^{-1} \mathrm{M}$ であるが, 両者共 存時のピラジナミドとイソニアジドの最高濃度はそれぞ 
Table 1. Total Solubility of Pyrazinamide in Water fontaing Isaniazid at $2^{\circ}$

\begin{tabular}{|c|c|c|}
\hline $\begin{array}{l}\text { isoniazid added } \\
\text { to system concn. } \\
\times 10^{-1} \mathrm{M}\end{array}$ & $\begin{array}{l}\text { total pyrazin- } \\
\text { amide at satura- } \\
\text { tion concn. } \\
\times 10^{-1} \mathrm{M}\end{array}$ & $\begin{array}{l}\text { Equilitb. } \\
\text { const. (L/M) }\end{array}$ \\
\hline $\begin{array}{r}0.00 \\
1.46 \\
2.92 \\
4.37 \\
5.84 \\
7.29 \\
8.02 \\
8.75 \\
9.48 \\
10.21 \\
10.94 \\
11.67 \\
12.04 \\
12.24 \\
12.39 \\
13.13 \\
13.85 \\
14.22 \\
14.58\end{array}$ & $\begin{array}{l}1.30 \\
1.51 \\
1.73 \\
1.97 \\
2.15 \\
2.37 \\
2.50 \\
2.61 \\
2.73 \\
2.81 \\
2.89 \\
2.92 \\
3.00 \\
3.08 \\
3.04 \\
3.12 \\
3.06 \\
3.08 \\
3.10\end{array}$ & $\begin{array}{l}1.29 \\
1.33 \\
1.39 \\
1.31 \\
1.32 \\
1.35 \\
1.35 \\
1.37 \\
1.34 \\
1.31 \\
1.24 \\
1.26 \\
1.31 \\
1.26 \\
1.24 \\
1.12 \\
1.10 \\
1.08 \\
\end{array}$ \\
\hline 14.58 & & Av. 1.28 \\
\hline
\end{tabular}

$\mathrm{X}$ : Values column 1

$\mathrm{Y}$ : Values column 2

れ $3.08 \times 10^{-1} \mathrm{M}$ と $12.24 \times 10^{-1} \mathrm{M}$ となる (Fig. 1). 従ってピラジナミドとイソニアジドの共存時における両 者の溶解度增加の比は $\left(3.08 \times 10^{-1} \mathrm{M}\right)-\left(1.30 \times 10^{-1} \mathrm{M} \mathrm{M}\right)$ $/\left(12.24 \times 10^{-1} \mathrm{M}\right)-\left(10.43 \times 10^{-1} \mathrm{M}\right)=1.78 \times 10^{-1} \mathrm{M} /$

$1.81 \times 10^{-\mathrm{x}} \mathrm{M}=0.98$ となり,ピラジナミドとイソニアジ ドは1：1の割合で錯体を形成することが推定されるの で, 次の式 (1) を適用して錯体形成の安定度定数 Kc を計算した (Table 1).

Pyrazinamide+Isoniazide Kc

Pyrazinamide-Isoniazid

Table 1 の第 1 列の数值を $\mathrm{X}$ とし, 第 2 列の数值を $\mathrm{Y}$ とすれば式 (1)より Kc は次の計算式によって求められ ろ.

$$
\begin{array}{r}
\mathrm{Kc}=\left(\mathrm{Y}-1.30 \times 10^{-1} \mathrm{M}\right) /\left(1.30 \times 10^{-1} \mathrm{M}\right) \\
\left\{\left[\mathrm{X}-\left(\mathrm{Y}-1.30 \times 10^{-1}\right] \mathrm{M}\right\}\right.
\end{array}
$$

\section{秸語}

ピラジナミドは水に難溶性であるが, イソニアジドの 共存下では, 両者の溶解度が増加する。この溶解度（モ

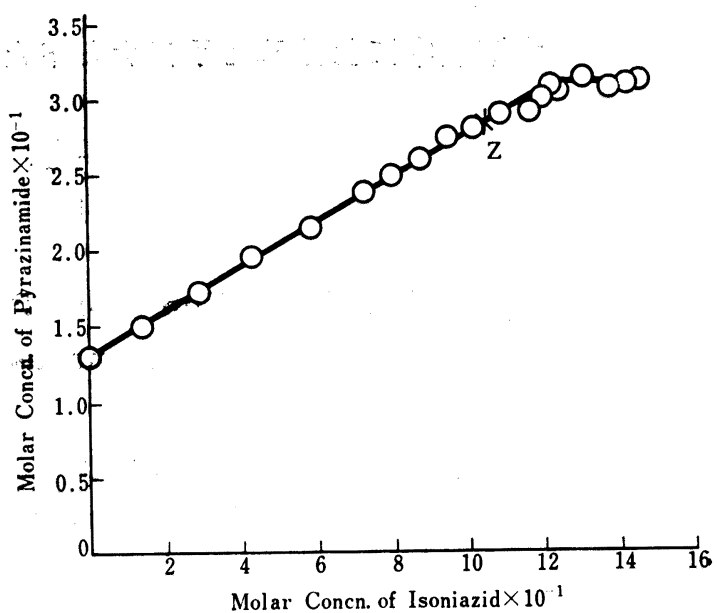

Fig. 1. Phase Diagram of PyrazinamideIsoniazid System in Water at $25^{\circ}$ Molar concn. of solubilized pyrazinamide is plotted against molar concn. of isoniazid Point $Z(X)$ on the diagram represents the solubility limit of isoniazid

ル漕度）の增加の比が 0.98 であることからピラジナミ ドとイソニフジドが $1 ： 1$ の割合で錯体を形成すること が推察される. また平衡定数 $\mathrm{Kc}$ が，実検浱度の全範囲 にわたってほぼ一定の数值を示すこともこのことを支持 している.

的辞 本研究に際し御指導いたたいた元名古屋市立大学 薬学部冢本長太郎数授に感詩いたします。

文

1) G. B. Maekaness : Am. Rev. Tuber Pulmonary Diseae, 74, 718 (1956).

Walsh Me Dermott, Louise Ormond, Carl Mushenhein, Kurt Deuschle, Robert M, Me-cvme, Jr., and Rulph Tompsett : ibid, 69, 319 (1954).

2) 田村一雄, 塚本長太郎：萖凨学, 33, 200 (1973).

3) Takeru Higuchi and John. L. Lach : J. Amer. Pham. Assoc. Sci., 43, 349 (1954).

4）第八改正日本薬局方第一部解説書, 広川書店, C 1394 (1971).

5) 田村一雄: 薬凨学, 32, 150 (1972). 